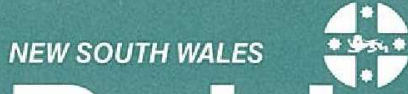 Public

\section{BLUE-GREEN ALGAE HIT LAKE CARGELLIGO}

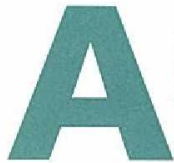

ustralia has had its first instance of the prohibition for human consumption of a town water supply because of a bloom of toxin-producing blue-green algae. The Department of Water Resources issued a media warning on November 20 last year that a high concentration of the potentially toxic blue-green algae, species Anabaena circinalis, had been detected in the water of Lake Cargelligo, 570km west of Sydney. On November 25 the Lachlan Shire Council warned that people should not drink water from the lake, even if boiled, because the algal toxin is heat stable.

Some of these algae produce powerful liver and neurotoxins ${ }^{1}$. Livestock deaths have occurred when thirsty animals were forced to drink the algal scum. In humans there have been some reports of illness caused by blue-green algae, also called cyanobacteria. Swimmers and canoeists have reported hay-fever like reactions, rash, eye irritation and pneumonia ${ }^{2}$.

In 1979 a major outbreak of diarrhoea possibly associated with mild liver damage occurred in an Aboriginal community on Palm Island in Queensland after copper sulphate was used to treat a bloom of cyanobacteria in the local reservoir ${ }^{3}$. It is probable that this treatment caused the large amounts of toxin to be suddenly released into the water. Problems of odour and taste caused by algae have been reported in the water supply of a number of towns in rural NSW and Victoria.

The most abundant bloom-forming species of blue-green algae in Australia are Microcystis aeruginosa and Anabaena circinalis. About half the blooms are toxic. Unfortunately, the only method available to assay toxicity is to inject dried algal extract into mice. This is a timeconsuming procedure which is performed at only one centre in NSW. But other test tube methods, such as high performance liquid chromatography and ELISA antibody tests, are being developed.

Three communities - Lake Cargelligo, Tullibigeal and Murrin Bridge - with a total population of 2000 , draw their water directly from the lake. However, 40 per cent of houses in these communities are also served with rainwater tanks. Despite the contamination, the town water supply was not shut off because of the extreme fire danger in the area at the time. The Central West Public Health Unit continued to issue warnings about the hazards of drinking town water, assisted by local community groups.

Drinking water was delivered in tankers to Lake Cargelligo from Condobolin, $100 \mathrm{~km}$ away.

Records of absenteeism for gastrointestinal illness from October 28 to November 30 were examined for 563 children attending the schools and preschools at Lake Cargelligo and Tullibigeal. There were reticulated and tank water outlets in the school playgrounds, making it impossible to determine whether children had consumed

\section{Contents}

\section{Articles}

110 Lake Cargelligo bit by blue-green algae

111 Firearm injuries in NSW

113 Nitrates in water cause of family's problems?

115 Quality versus quantity

117 Public bealth abstracts

\section{Infectious diseases}

119 Reported scarlet fever outbreak

121 Hepatitis annual report

122 Nolifications

\section{Correspondence}

Please address all correspondence and potential contributions to:

\section{The Editor,}

NSW Public Health Bulletin,

Public Health Division,

Department of Health, NSW

Locked Bag No 961,

North Sydney NSW 2059

Telephone: (02) 3919219

Facsimile: (02) 3919232 


\section{NitRATES IN BORE WATER: CAUSE}

n June 1991 a member of a large extended family living on a small hobby farm near Oberon, NSW, contacted the Orana and Far West Public Health Unit for advice about the family's bore water supply. Tests conducted on water drawn from a bore on the property showed that it contained $38 \mathrm{mg} / \mathrm{L}$ nitrate (as nitrogen) and was unfit to drink. On the day these results became available the family switched to drinking rainwater exclusively. Within a few days of doing this, health problems experienced by the whole family disappeared.

All 10 family members, ranging in age from 6 to 65 , had a six-month history of symptoms of breathlessness, fatigue, chest pain and muscle cramps (Figure 1). The three adult males were employed and spent most of their weekdays away from the farm. Two of the men had relatively minor symptoms. The third male was the most severely affected family member. He also worked in town but he drank large quantities of tea and coffee while at home (20-30 cups a day). He had severe and persistent muscle cramps for more than six months. A subsequent muscle biospy was normal. All female family members spent most of their time on the farm and the children were educated at home. The family had consulted its local general practitioner who corroborated this history. Sheep and peacocks on the property also drank bore water and have been unwell.

The family has lived on this farm for three years. Its members eat a mixed diet of meat and vegetables. Spinach and lettuce are grown in the garden and watered with bore

\section{Blue-green algoe at Lake Cargelligo}

\section{Continued from page 110}

\section{TABLE 2}

\section{SYMPTOMS AMONG 95}

LAKE CARGELLIGO SCHOOL CHILDREN

$\begin{array}{ll}\text { Nausea } & 74(79 \%) \\ \text { Abdominal cramp } & 57(60 \%) \\ \text { Headache } & 54(57 \%) \\ \text { Vomiting } & 37(39 \%) \\ \text { Fever } & 12(13 \%)\end{array}$

contaminated water. Ninety-five children ( 17 per cent) were ill during this period. The frequency of reported symptoms is shown in Table 2.

The two medical practitioners at Lake Cargelligo had seen about 20 adults and children in the previous month with symptoms believed to be those of viral gastroenteritis. Two instances of conjunctivitis and one of a rash had been attributed to swimming in the lake. Liver function tests were performed in eight of these people and all results were normal. In the four patients in whom viral blood tests were performed, the results were inconclusive.

On December 24 the Lake Cargelligo water supply was proclaimed safe for human consumption. The bloom of Anabaena disappeared but of concern was a subsequent bloom of another potentially toxic algae, Microcystis. The NSW Department of Water Resources predicted that bluegreen algal blooms are likely to recur in Lake Cargelligo this summer. Weekly monitoring and toxicity assays are to be instituted.

\section{EDITORIAL NOTE}

Ensuring the provision of uncontaminated drinking water has been a canon of public health practice since the time of John Snow. Across much of the Australian continent potable water supplies are threatened by the eutrophication of our inland lakes and rivers. Eutrophication is an alteration in the balance of nutrients such as phosphates in these waterways, favouring the proliferation of bluegreen algae (cyanobacteria) and other unwanted microorganisms. The major causes of eutrophication are phosphate- and nitrate-based fertilisers and sewage from human population centres and livestock. Australian Bureau of Statistics data ${ }^{4}$ indicate that total tonnage of superphosphate fertilisers used in the Central West of NSW increased by 21.8 per cent in the two years from 1986 to 1988 . Even more significantly, the use of superphosphate fertilisers in the Central Tablelands statistical subdivision, where the Lachlan River which flows into Lake Cargelligo rises, increased by 94.3 per cent in the same period.

The most likely explanation of the apparent infrequency of human illness caused by algal toxins is that the unpleasant taste and odour of the contaminated water is an effective deterrent to ingestion. The potential toxicity of long-term, low-dose exposure to these toxins or their effect on sensitive subgroups in the population is unknown.

The Palm Island incident is an illustration of why copper sulphate has fallen into disrepute as an effective treatment for algal blooms. Furthermore, the elimination of one species, as was seen in Lake Cargelligo, can rapidly be followed by an overgrowth of a different species. Rainfall or increased flows can flush out a bloom. Individual town water supplies can be secured by the installation of charcoal filtration systems. In the long term, prevention of eutrophication of inland waterways will depend on changes in methods of waste water treatment, agricultural and land management practices.

Peter Christopher, Director, Public Health Services, Central Western Region

Peter Davis, Medical Practitioner, Lake Cargelligo

Ian Falconer, Dean, Faculty of the Sciences,

University of New England, Armidale

Lee Bowling, Deputy Water Quality Manager, Storages; Senior Biologist, Department of Water Resources

John Dyson, Chief Health Surveyor,

Lachlan Shire Council, Condobolin

Acknowledgements: We are thankful for the assistance and advice received from Mr D. Clarke, Chief Executive Officer of Lake Cargelligo Hospital and his staff; Mr G. Thomas, Eastern Area Health Services; Mrs K. Stenhouse Lake Cargelligo Central School: the staff of Applied Chemical Laboratories, Sydney; Dr D. Fox and Dr S. Corbett of the NSW Health Department.

1. Falconer IR. Eutrophication by toxic blue-green algae. An increasing health hazard in Australia. Australian Biologist 1988, 1:10-12. 2. Turner PC, Gammie AJ, Hollinrake K and Codd GA. Pneumonia associated with cyanobacteria. Brit J Med 1990, 300:1440-1441. 3. Hawkins PR, Runnegar MT, Jackson ARB, Falconer IR. Severe hepatotoxicity caused by the tropical cyanobacterium (blue-green algae) Cylindrospermopsis racibarskii (Woloszynska) Seenaya and Subba Raju isolated from a domestic water supply reservoir. Applied and Environmental Microbiology 1985, 50,5:1292-1295.

4. Australian Bureau of Statistics. Agricultural Land Use and Selected Inputs, NSW, 1987-88. Cat. No. 7411.1. ABS Sydney 1989. 